\title{
Thermodynamics of sorption of platinum on superparamagnetic nanoparticles functionalized with mercapto groups
}

Andrea Melchior,

Sara Gràcia Lanas, 1,2

Manuel Valiente, 2

Marilena Tolazzi, 1 四

Emailmarilena.tolazzi@uniud.it

${ }^{1}$ Laboratorio di Scienze e Tecnologie Chimiche, Dipartimento Politecnico di Ingegneria e Architettura, Università di Udine, Via del Cotonificio 108, 33100 Udine, Italy

2 Departamento de Quimica, Centre GTS, Universitat Autònoma de Barcelona, Campus Bellaterra Edificio CN, Barcelona, Spain

Received: 11 December 2017 / Accepted: 23 May 2018

\section{Abstract}

The adsorption of $\mathrm{Pt}(\mathrm{IV})$ by iron oxide $\left(\mathrm{Fe}_{3} \mathrm{O}_{4}\right)$ superparamagnetic nanoparticles (SPION) functionalized with 3-mercaptopropionic acid (3MPA) is investigated by means of inductively coupled plasma optical emission spectrometry and isothermal titration calorimetry. Experimental ICP data are better fitted by Langmuir rather than Freundlich isotherms. The whole thermodynamic parameters and maximum loading capacity for the adsorption process of $\mathrm{Pt}(\mathrm{IV})$ on the functionalized SPION nanoparticles (SPION@3-MPA) are obtained. The process is enthalpy-driven, while 
entropy is largely unfavourable suggesting that some other interaction should be present in addition to the electrostatic ones with the coverage surface. When compared to other thiol-functionalized materials, the SPION@3-MPA can be considered an interesting adsorbent for Pt(IV), especially with respect to the short contact time evidenced.

\section{$\mathrm{AQ1}$

\section{Introduction}

The special properties displayed by platinum such as chemical inertness, high corrosion resistance, high melting temperature determine the large range of application of the metal [1]. Platinum finds application in the manufacturing of electronic and electrical devices, catalysts, jewellry, biomedical devices, fuel cell production, plating and coatings, and many more products. Because of the increasing demand for platinum in various industries, and the limited natural resources available, the recovery of the metal from aqueous solutions is economically attractive. Also the treatment of hospital liquid waste containing CPC (cancerostatic platinum compounds) compounds originated has become a growing topic in the last decade, since the dispersion in sewage water of such mutagenic compounds is highly undesirable. The methods for the recovery of platinum from aqueous solutions include precipitation, co-precipitation, liquidliquid extraction and adsorption [2,3].

Among these methods, adsorption technology has proven to be one of the best techniques for metal wastewater treatment because it offers flexibility in design and operation [4]. Furthermore, since this process is often reversible, adsorbed species can be recovered by suitable desorption process and the material regenerated for its reuse.

Nanoparticles attracted much attention for metal ion recovery from water because of their high surface area to volume ratio, fast reaction kinetics, the possibility to be chemically modified on their surface $[4,5,6]$. These materials can be then separated from the liquid samples with relatively simple methods. Among them, nano-sized metal oxides demonstrated to be promising materials for metal removal from wastewaters $[4,6,7]$. As an example, in several recent 
studies functionalized materials have been used as adsorbents for platinum(IV) in aqueous solution [8].

Recently, super paramagnetic iron oxide nanoparticles (SPION) received special attention for their low toxicity, low cost and easy recovery from aqueous media by magnetic separation $[4,9,10]$. In addition, iron is one of the widespread elements in the earth and easily accessible [11], rendering the material a lowcost adsorbent which is a requisite for wastewaters treatment. It is also important to develop protection strategies to stabilize the magnetic nanoparticles against their degradation, such as core-shell, which are also used for functionalization of the adsorbent material for selective application. Hence, if the surface of magnetite is coated with a compound containing a thiol or amino group, the removal of metals should be enhanced enabling, in addition, the magnetic separation of the adsorbent from the solution $[8,12,13,14,15$, $16]$.

In this work, the adsorption of $\mathrm{Pt}(\mathrm{IV})$ on iron oxide $\left(\mathrm{Fe}_{3} \mathrm{O}_{4}\right)$ SPION functionalized with 3-mercaptopropionic acid (SPION@MPA) is studied by means of inductively coupled plasma optical emission spectrometry (ICP-OES) technique in parallel with isothermal titration calorimetry (ITC). The aim is to investigate the efficiency of the nano-adsorbent but also to gain parameters on the thermodynamic of adsorption of Pt(IV) by functionalized SPION@MPA.

The organic ligand 3-MPA has been selected as promising ligand for surface functionalization of magnetite nanoparticles. It contains a carboxyl group, which facilitates the coating with iron oxide due to the high affinity of the carboxyl group towards iron [7], whereas the additional thiol group has shown good adsorption properties for noble-metal ions and some other metals $[8,12$, $13,14,15,16]$.

The use of calorimetry is a novel approach used here to quantify an adsorption process from aqueous solution to solid phase. Indeed, this technique was widely used by our group mainly to characterize chemical equilibria processes in aqueous or non-aqueous solutions [17, 18, 19, 20, 21, 22, 23, 24, 25, 26]. Meanwhile, a few number of ITC applications in adsorption studies are found in the recent literature $[27,28,29,30]$, being the enthalpy associated with desorption process usually calculated indirectly by van't Hoff equation [31, 32]. Nevertheless, many studies revealed serious discrepancies between enthalpy values calculated from van't Hoff equation and obtained directly from ITC and, 
evidencing large uncertainties associated with the former method [33, 34, 35, 36]. On the contrary, ITC analysis provides independent and robust thermodynamic parameters, which allows to gain information of specificity of functionalization towards metal ions adsorption and about the possible nature of the interactions at play between the surface and the anionic ligand.

\section{Experimental}

\section{Material preparation}

All reagents used in the experiment were analytical grade and used without further purification. Ammonium hydroxide $\left(\mathrm{NH}_{4} \mathrm{OH}\right)$, hydrochloric acid $(\mathrm{HCl})$, iron (II) chloride $\left(\mathrm{FeCl}_{2} \cdot 4 \mathrm{H}_{2} \mathrm{O}\right)$, iron (III) chloride $\left(\mathrm{FeCl}_{3} \cdot 6 \mathrm{H}_{2} \mathrm{O}\right)$ and 3 mercaptopropionic acid (3-MPA) were purchased from Sigma-Aldrich.

The metal stock solution was prepared by dissolving hydrogen hexachloroplatinate (IV) hydrate (Aldrich) in $\mathrm{HCl}$ solutions prepared in milliQ water.

Iron oxide nanoparticles were synthesized by a co-precipitation method, as described elsewhere $[15,16,37]$.

The SPION were functionalized with 3-MPA (SPION@3-MPA) by ligand addition method [15]. A known amount of synthesized SPION was suspended in water acidified with $\mathrm{HNO}_{3}$ to $\mathrm{pH}=2.0$, to have the surface charged positively $\left(\mathrm{pH}_{\mathrm{pzc}}\right.$ of the $\left.\mathrm{SPION}=6.8\right)$ [38]. Then, $10 \mathrm{~mL}$ of SPION suspension were stirred for $24 \mathrm{~h}$ in $\mathrm{N}_{2}$ atmosphere, with a solution of the 3-MPA $150 \mathrm{mM}$ in toluene. After phase separation using magnetic decantation, the particles were washed with ethanol, dried at room temperature and stored in dry box in $\mathrm{N}_{2}$ atmosphere. The nanoparticles were characterized as previously described in Ref. [15] by means of BET (Micromeritics Tristar 3000 gas adsorption analyzer), FT-IR and thermogravimetry (Q500 TGA, TA Instruments). The $\mathrm{pH}_{\mathrm{pzc}}$ of SPION@3-MPA was determined following the published methodology [39]. The overall results on the characterization of the SPION@3-MPA resulted to be in good agreement with Ref. [15].

\section{Adsorption studies}

The adsorption experiments for Pt(IV) were performed at $298 \pm 1 \mathrm{~K}$ by suspending 5 mg of SPION@3-MPA to 10 mL solutions containing the metal 
ion in the $0.1-1.0 \mathrm{mM}$ concentration range. The $\mathrm{pH}$ of the solution was adjusted at $\mathrm{pH}=3.0$ with $\mathrm{HCl}$ where the main $\mathrm{Pt}(\mathrm{IV})$ species should be $\mathrm{PtCl}_{6}{ }^{2-}$ and $\mathrm{PtCl}_{5}\left(\mathrm{H}_{2} \mathrm{O}\right)^{-}$complex $[8,37,40]$. The $\mathrm{pH}$ value was chosen in order to avoid the hydrolysis of chloro-complex of $\mathrm{Pt}(\mathrm{IV})($ at $\mathrm{pH}>3.5)$ [41] and the eventual dissolution of magnetic particles $($ at $\mathrm{pH}<2$ ).

The suspension was sonicated for $30 \mathrm{~min}$ and then allowed $2 \mathrm{~h}$ in contact, due to a relatively low kinetic of adsorption of $\mathrm{Pt}(\mathrm{IV})$. In preliminary experiments, the contact time necessary between nanoparticles and $\mathrm{Pt}(\mathrm{IV})$ was found to be about $100 \mathrm{~min}$, as no significant variation of adsorption \% was observed after that time. The magnetic adsorbent was separated from the aqueous phase, and the $\mathrm{Pt}(\mathrm{IV})$ concentration in the filtered solution was determined by ICP-OES (Varian VISTA-MPX CCD Simultaneous ICP-OES). Iron content was also determined to control the particle dissolution, which did not occur in our experimental conditions.

AQ5

Adsorption data were fitted by the Langmuir and Freundlich isotherms, as it has been demonstrated that such models better fit the adsorption from solutions [42]. These models are expressed by Eqs. 1 and 2, respectively [43]:

$$
C_{\mathrm{ads}}=\frac{Q_{\max } b C_{\mathrm{e}}}{1+b C_{\mathrm{e}}}
$$

$C_{\mathrm{e}}$, solute equilibrium concentration (M); $C_{\mathrm{ads}}$, solute adsorbed at equilibrium (mol g $\left.{ }^{-1}\right) ; Q_{\max }$, maximum quantity of solute adsorbed per gram of adsorbent $\left(\mathrm{mol} \mathrm{g}^{-1}\right)$ and $b$, Langmuir constant $\left(\mathrm{M}^{-1}\right)$.

$$
C_{\mathrm{ads}}=K_{\mathrm{f}} C_{\mathrm{e}}^{\frac{1}{n}}
$$

$K_{\mathrm{f}}$, Freundlich constant ( $\left.\left(\mathrm{L} \mathrm{mmol}^{-1} \mathrm{~g}^{-1}\right)^{1 / n}\right) ; n$, adsorption intensity; $C_{\mathrm{e}}$, equilibrium concentration of adsorbate $(M) ; C_{\mathrm{ads}}$, amount of $\mathrm{Pt}$ adsorbed at equilibrium $\left(\mathrm{mol} \mathrm{g}^{-1}\right)$.

\section{Isothermal titration calorimetry (ITC)}

A TAMIII isothermal microcalorimeter (TA Instruments) connected with an automatic titration syringe was used to measure the heat of adsorption of the Pt(IV) metal ion on SPION@3-MPA. The titration cell was filled with a solution at $\mathrm{pH}=3.0$ (adjusted by $\mathrm{HCl}$ ) in which $\sim 0.5 \mathrm{~g} \mathrm{~L}^{-1}$ SPION@3-MPA 
were dispersed. The suspension was stirred continuously at $120 \mathrm{rpm}$. The cell content was titrated with 14 additions of $14 \mu \mathrm{L}$ of $5 \mathrm{mM}$ metal ion solution. A delay time of $2 \mathrm{~h}$ between consecutive injections was allowed, because of $\mathrm{Pt}(\mathrm{IV})$ slow kinetics. The reference cell was filled with $0.7 \mathrm{~mL}$ of MilliQ water. AQ6

The values of $b$ and $Q_{\max }$ obtained by the fit of the Langmuir isotherm obtained from ICP-OES data, have been used as input data in Eq. 3 to calculate $C_{\mathrm{e}}$ for each titrant addition by numerically solving Eq. 1 with the same experimental conditions as the calorimetric titrations $[44,45]$. Then, the $\Delta H_{\mathrm{ads}}\left(\mathrm{kJ} \mathrm{mol}^{-1}\right)$ value has been calculated to best fit the experimental heat according to the isotherm (Eq. 3):

$$
q_{\mathrm{cum}}=\frac{Q_{\mathrm{max}} b C_{\mathrm{e}}}{1+b C_{\mathrm{e}}} \Delta H_{\mathrm{ads}}
$$

$q_{\text {cum }}=$ total heat involved at each titrant addition per gram of SPION@3-MPA $\left(\mathrm{kJ} \mathrm{g}^{-1}\right)$. Dilution heat $\left(q_{\text {dil }}\right)$ was also determined to correct the total heat measured $\left(q_{\text {meas }}\right)$ by the instrument. Thus, $q_{\text {cum }}=\left(q_{\text {meas }}-q_{\text {dil }}\right) / w$ represents only the heat involved on the adsorption reaction. Data fitting and statistical analysis of the results has been done with the MS-Excel Solverstat and EST tools [46, 47] (Fig. 1).

\section{Fig. 1}

Functionalization mechanism of 3-MPA on SPION $(=\equiv \mathrm{Fe})$ surface

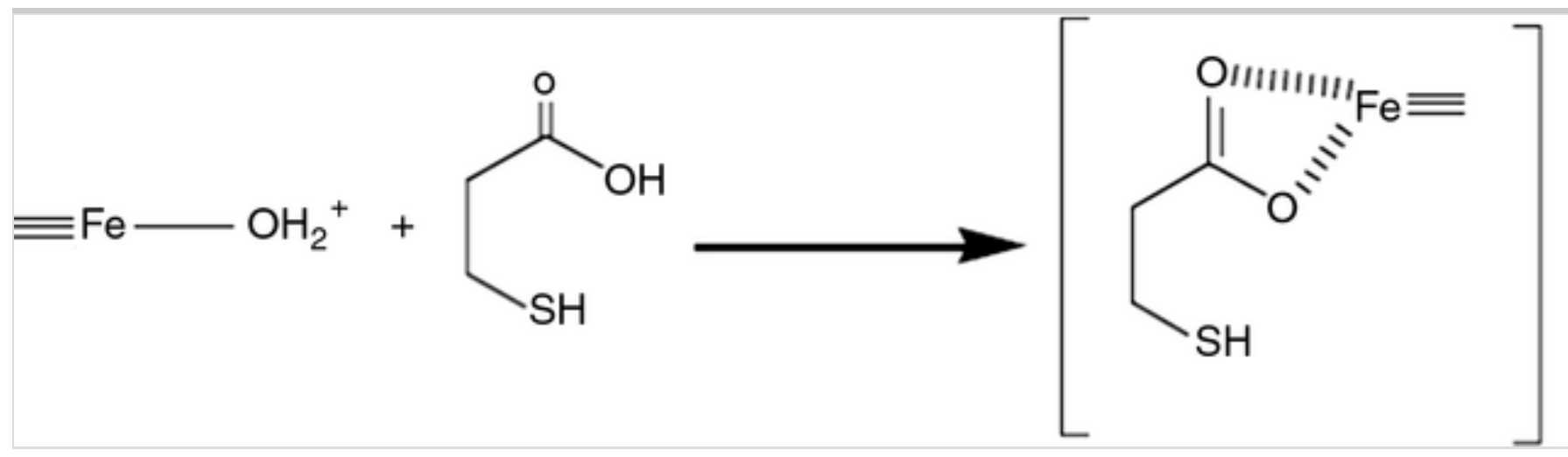

\section{Results and discussion}

The adsorption data have been fitted with Langmuir and Freundlich isotherms, 
and the obtained parameters are summarized in Table 1, while the experimental points and calculated curves are reported in Fig. 2. The best fit is obtained with the Langmuir isotherm as evident from the significantly higher quality of the fit (higher $R^{2}$, Table 1 and Fig. 2), indicating the presence of a homogeneous adsorption by the formation of a monolayer adsorbate on the adsorbent surface.

Table 1

Langmuir and Freundlich isotherm parameters for Pt(IV) by SPION@3-MPA at $\mathrm{pH}=3.0$

\begin{tabular}{|c|c|c|c|c|c|c|c|}
\hline & \multicolumn{4}{|c|}{ Langmuir equation } & \multicolumn{3}{|c|}{ Freundlich equation } \\
\hline & $Q_{\max } / \mathrm{mol} \mathrm{g}^{-1}$ & $b\left(\mathbf{M}^{-1}\right)$ & $\begin{array}{l}\log \\
b\end{array}$ & $R^{2}$ & $n$ & $K_{\mathrm{f}} / \mathbf{L} \mathrm{mmol}^{-1} \mathrm{~g}^{-1}$ & $R^{2}$ \\
\hline $\operatorname{Pt}(\mathrm{IV})$ & $\begin{array}{l}0.00031 \pm \\
0.00001\end{array}$ & $\begin{array}{l}368483 \\
\pm 129319\end{array}$ & $\begin{array}{l}5.6 \\
\pm \\
0.3\end{array}$ & 0.997 & $\begin{array}{l}12 \\
\pm 2\end{array}$ & $0.342 \pm 0.008$ & 0.951 \\
\hline
\end{tabular}

Fig. 2

Adsorption isotherms showing the experimental data fitted with Langmuir (solid line) and Freundlich (dashed line) models. In the batch experiments, $5 \mathrm{mg}$ of the SPION@3-MPA were added to $10 \mathrm{~mL}$ of the metal solutions, with a metal concentration varying from 0.1 to $1.0 \mathrm{mM}$

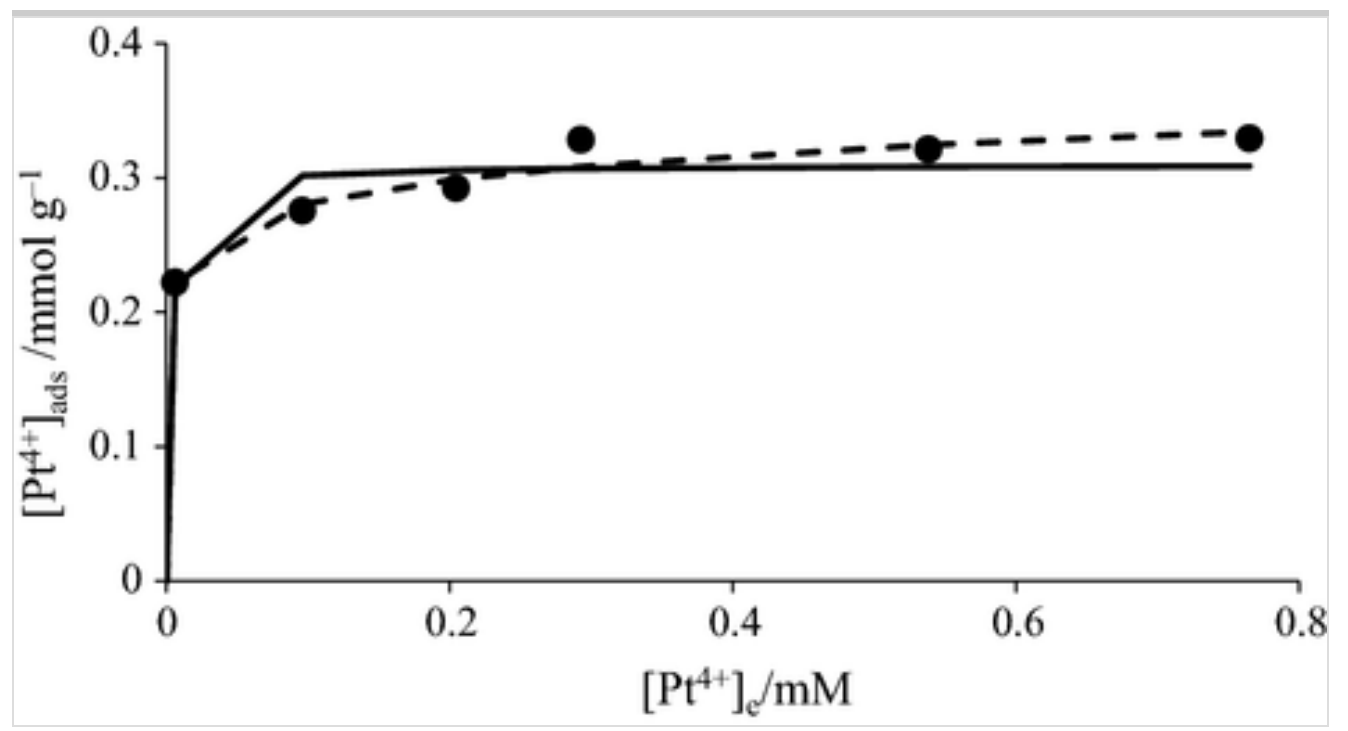

The calorimetric titration of the SPION@3-MPA suspension is shown in Fig. 3a, while the experimental and calculated $q_{\text {cum }}$ values are reported in Fig. $3 \mathrm{~b}$ as obtained by using Eq. 3. The corresponding $\Delta H_{\text {ads }}$ is reported in Table 2 
together with the calculated entropy values. A strong exothermic effect ( $\Delta H_{\text {ads }}$ $\left.=-50 \mathrm{~kJ} \mathrm{~mol}^{-1}\right)$ is associated with the process together with a high negative entropy value $\left(\mathrm{T} \Delta S_{\mathrm{ads}}=-18.2 \mathrm{~kJ} \mathrm{~mol}^{-1}\right)$, as calculated by the $\Delta G$ value obtained from b value $\left(\Delta G_{\text {ads }}=-31.8 \mathrm{~kJ} \mathrm{~mol}^{-1}\right)$ in Table 1 . In a recent work [48], negative enthalpy and entropy values were obtained for the interaction of $\mathrm{Cr}(\mathrm{VI})$ with a nano-composite adsorbent based on grafted

$\mathrm{Fe}_{3} \mathrm{O}_{4} /$ poly(methylmethacrylate) $\left(\Delta H=-97.5 \mathrm{~kJ} \mathrm{~mol}^{-1} \Delta S=-320 \mathrm{~J} \mathrm{~mol}^{-1} \mathrm{~K}\right.$ $-1)$.

\section{Fig. 3}

Calorimetric titrations plots corresponding to the addition of $\mathrm{Pt}(\mathrm{IV})$ solution to $0.7 \mathrm{~mL}$ of $0.5 \mathrm{~g} \mathrm{~L}^{-1}$ SPION@3-MPA suspension (a), and experimental calorimetric data (points) fitted with Eq. 3 (line) for Pt(IV) adsorption process (b)

(a)

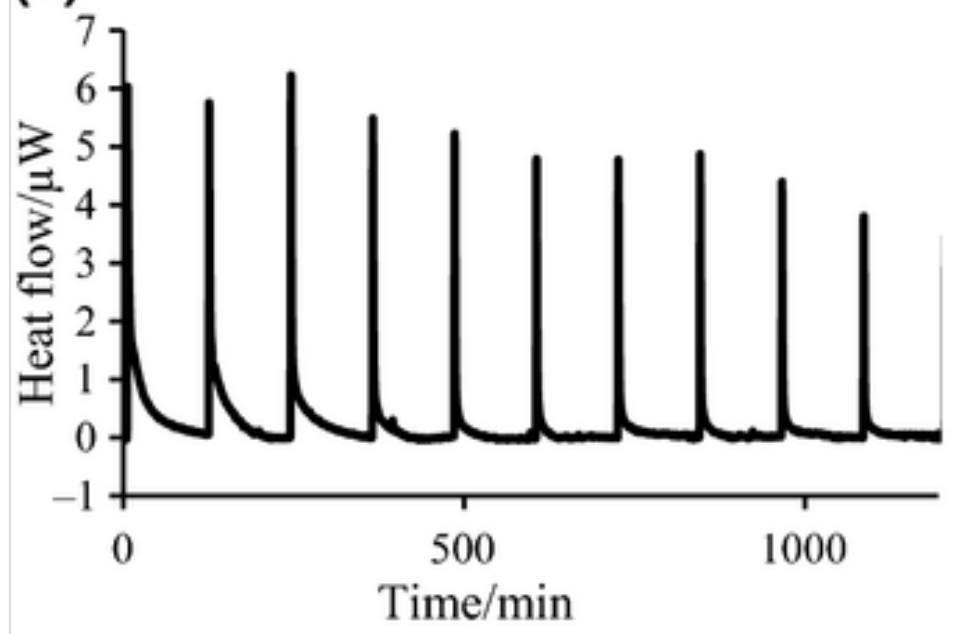

(b)

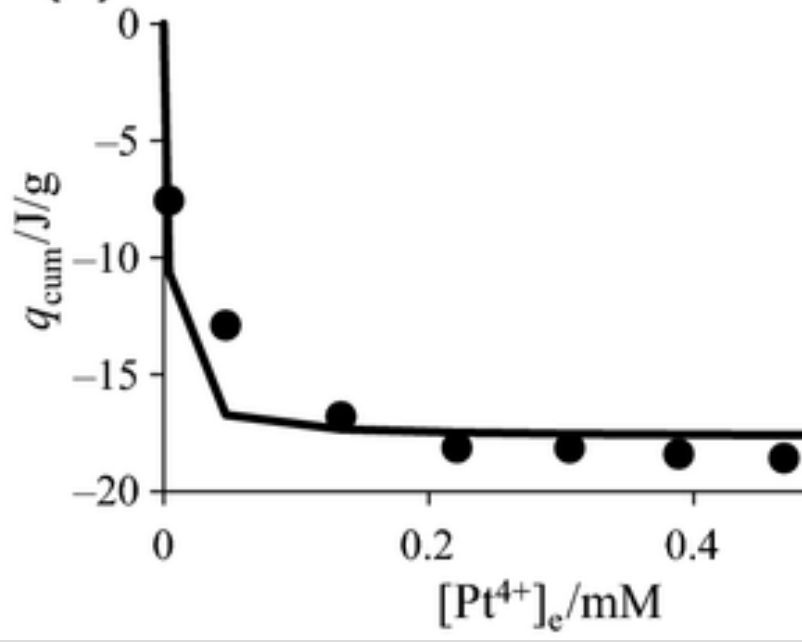

Table 2

Parameters of Pt(IV) adsorption for several thiol-functionalized adsorbents

\begin{tabular}{|l|l|l|l|l|l|l|}
\hline Adsorbent & $\mathbf{S \% / m m o l ~ g - 1 ~}$ & $\begin{array}{l}\text { Initial } \\
\mathbf{M}^{\mathbf{n}} / \mathbf{m M}\end{array}$ & $\begin{array}{l}\text { Adsorbent } \\
\mathbf{d o s a g e / g} \mathbf{L}^{-1}\end{array}$ & $\mathbf{p H}$ & $\mathbf{T e m p . / K}$ & $\begin{array}{l}\text { Con } \\
\mathbf{t i m}\end{array}$ \\
\hline $\begin{array}{l}\text { Magnetic } \\
\text { cellulose } \\
\text { functionalized } \\
\text { with thiol and } \\
\text { amine }\end{array}$ & - & $\begin{array}{l}0.03-0.25 \\
(5-\end{array}$ & $0.04 \mathrm{~g}$ & 2.0 & 318 & 1 \\
\hline $\begin{array}{l}\text { Thiolated } \\
\text { mesoporous } \\
\text { silicas }\end{array}$ & $\begin{array}{l}2.4 \\
(7.59 \%)\end{array}$ & - & 1.0 & 2.0 & 298 & 48 \\
\hline Straw-SH & $\begin{array}{l}2.71 \\
(8.70 \%)\end{array}$ & - & - & 1.0 & Room & 24 \\
\hline
\end{tabular}




\section{Thiol-}

functionalized

mesoporous

silica

\section{SPION@3-}

MPA

1.4

$0.5-4$

1.0

1.0

In parentheses, the original values in the cited references are reported

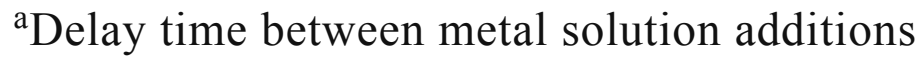

The low solvation of anions in water, as compared to cations [49], should partially account for the thermodynamic values relative to Pt(IV) adsorption, but also some concomitant effects atare probably at play.

Indeed, the adsorption mechanism could be due to the (i)-(i) coordination enof thiol group in a pendant fashion or in combination with vicinal hydroxyl groups and (ii)(ii) electrostatic attraction between charges of opposite sign. In our experimental conditions, $\mathrm{Pt}(\mathrm{IV})$ is in anionic form and the adsorbent surface is positively charged so electrostatic interactions are certainly possible.

Nevertheless, also some interaction with the thiol groups could be present. In any case, the fact that the anionic $\mathrm{PtCl}_{6}{ }^{2-}$ species is poorly solvated could be responsible of the negative $\Delta S$ : in this case the loss of degrees of freedom of the adsorbate prevails on the desolvation processes regarding the solute and the surface.

The adsorption efficiency of the SPION@3-MPA towards Pt(IV) $(0.31 \mathrm{mmol} g$ $\left.{ }^{-1}\right)$ is poorer with respect to other adsorbents as evidenced from the comparison with data reported in Table $2[50,51,52]$, but higher with respect to the adsorption capacity shown by magnetic cellulose functionalized with thiol and amine [8].

It is to underline that materials that reported a better efficiency than SPION@3MPA also showed a significant higher amount of sulphur present in the adsorbent (Table 2), which is related to the quantity of immobilized 3-MPA. This is a decisive factor for the sorbent ability of the material, and, in addition, some aggregation present on our adsorbent could be responsible of the lower efficiency. Despite that, SPION@3-MPA presents promising low contact time, which is a key parameter to be faced for possible applications. 


\section{Conclusions}

The present work presents a complete thermodynamic characterization of the adsorption of $\mathrm{Pt}(\mathrm{IV})$ by SPION functionalized with the ligand 3-MPA in acidic aqueous solution.

The Langmuir isotherm better fits experimental data providing the apparent stability constant and the maximum loading capacity. Direct calorimetric data show that the process is enthalpy-driven while entropy is largely unfavourable. If compared to other thiol-functionalized materials, the SPION@3-MPA can be considered an interesting adsorbent for Pt(IV) mainly with respect to the short contact time evidenced.

\section{Acknowledgements}

The research leading to these results has received funding from the European Community's H2020 Programme H2020-MSCA-RISE 2017 under the project RECOPHARMA with Grant Agreement no 778266.

\section{References}

1. Crabtree RH, Torrens H. Platinum: inorganic \& coordination chemistry. Encyclopedia of inorganic chemistry. Chichester: Wiley; 2006.

2. Fu F, Wang Q. Removal of heavy metal ions from wastewaters: a review. J Environ Manag. 2011;92:407-18.

3. Barakat MA. New trends in removing heavy metals from industrial wastewater. Arab J Chem. 2011;4:361-77.

4. Hua M, Zhang S, Pan B, Zhang W, Lv L, Zhang Q. Heavy metal removal from water/wastewater by nanosized metal oxides: a review. J Hazard Mater. 2012;211-212:317-31.

5. Qu X, Alvarez PJJ, Li Q. Applications of nanotechnology in water and wastewater treatment. Water Res. 2013;47:3931-46.

6. Khajeh M, Laurent S, Dastafkan K. Nanoadsorbents: classification, preparation, and applications (with emphasis on aqueous media). Chem Rev. 2013;113:7728-68. 
7. Warner CL, Addleman RS, Cinson AD, Droubay TC, Engelhard MH, Nash MA, Yantasee W, Warner MG. High-performance, superparamagnetic, nanoparticle-based heavy metal sorbents for removal of contaminants from natural waters. Chemsuschem. 2010;3:749-57.

8. Anbia M, Rahimi F. Adsorption of platinum(IV) from an aqueous solution with magnetic cellulose functionalized with thiol and amine as a nano-active adsorbent. J Appl Polym Sci. 2017;134:45361.

9. Yantasee W, Warner CL, Sangvanich T, Addleman RS, Carter TG, Wiacek RJ, Fryxell GE, Timchalk C, Warner MG. Removal of heavy metals from aqueous systems with thiol functionalized superparamagnetic nanoparticles. Environ Sci Technol. 2007;41:5114-9.

10. Singh N, Jenkins GJS, Asadi R, Doak SH. Potential toxicity of superparamagnetic iron oxide nanoparticles (SPION). Nano Rev. 2010;1:5358.

11. Ahn CK, Park D, Woo SH, Park JM. Removal of cationic heavy metal from aqueous solution by activated carbon impregnated with anionic surfactants. J Hazard Mater. 2009;164:1130-6.

12. Zhang S, Zhang Y, Liu J, Xu Q, Xiao H, Wang X, Xu H, Zhou J. Thiol modified $\mathrm{Fe}_{3} \mathrm{O}_{4} @ \mathrm{SiO}_{2}$ as a robust, high effective, and recycling magnetic sorbent for mercury removal. Chem Eng J. 2013;226:30-8.

13. Zhu H, Shen Y, Wang Q, Chen K, Wang X, Zhang G, Yang J, Guo Y, Bai R. Highly promoted removal of $\mathrm{Hg}(\mathrm{II})$ with magnetic $\mathrm{CoFe}_{2} \mathrm{O}_{4} @ \mathrm{SiO}_{2}$ coreshell nanoparticles modified by thiol groups. RSC Adv. 2017;7:39204-15.

14. Odio OF, Lartundo-Rojas L, Palacios EG, Martínez R, Reguera E. Synthesis of a novel poly-thiolated magnetic nano-platform for heavy metal adsorption. Role of thiol and carboxyl functions. Appl Surf Sci. 2016;386:160-77.

15. Morillo D, Uheida A, Pérez G, Muhammed M, Valiente M. Arsenate removal with 3-mercaptopropanoic acid-coated superparamagnetic iron oxide nanoparticles. J Colloid Interface Sci. 2015;438:227-34. 
16. Burks T, Avila M, Akhtar F, Göthelid M, Lansåker PC, Toprak MS, Muhammed M, Uheida A. Studies on the adsorption of chromium(VI) onto 3-Mercaptopropionic acid coated superparamagnetic iron oxide nanoparticles. J Colloid Interface Sci. 2014;425:36-43.

17. Cavallo L, Del Piero S, Ducéré J, Fedele R, Melchior A, Morini G, Piemontesi F, Tolazzi M. Key interactions in heterogeneous Ziegler-Natta catalytic systems : structure and energetics of $\mathrm{TiCl}_{4}$-lewis base complexes. J Phys Chem C. 2007;111:4412-9.

18. Melchior A, Peralta E, Valiente M, Tavagnacco C, Endrizzi F, Tolazzi M. Interaction of $\mathrm{d}(10)$ metal ions with thioether ligands: a thermodynamic and theoretical study. Dalton Trans. 2013;42:6074-82.

19. Di Bernardo P, Zanonato PL, Melchior A, Portanova R, Tolazzi M, Choppin GR, Wang Z. Thermodynamic and spectroscopic studies of lanthanides (III) complexation with polyamines in dimethyl sulfoxide. Inorg Chem. 2008;47:1155-64.

20. Melchior A, Peressini S, Portanova R, Sangregorio C, Tavagnacco C, Tolazzi M. Cobalt(II) and cadmium(II) chelates with nitrogen donors and $\mathrm{O}_{2}$ bonding to Co(II) derivatives. Inorganica Chim Acta. 2004;357:3473-82.

21. Del Piero S, Di Bernardo P, Fedele R, Melchior A, Polese P, Tolazzi M. Affinity of polypyridines towards $\mathrm{Cd}(\mathrm{II})$ and $\mathrm{Co}(\mathrm{II})$ ions: a thermodynamic and DFT study. Eur J Inorg Chem. 2006;2006:3738-45.

22. Melchior A, Gaillard C, Gràcia Lanas S, Tolazzi M, Billard I, Georg S, Sarrasin L, Boltoeva M. Nickel(II) complexation with nitrate in dry $\left[\mathrm{C}_{4}\right.$ $\operatorname{mim}]\left[\mathrm{Tf}_{2} \mathrm{~N}\right]$ ionic liquid: a spectroscopic, microcalorimetric, and molecular dynamics study. Inorg Chem. 2016;55:3498-507.

23. Endrizzi F, Di Bernardo P, Zanonato PL, Tisato F, Porchia M, Ahmed Isse $\mathrm{A}$, Melchior $\mathrm{A}$, Tolazzi $\mathrm{M}$. $\mathrm{Cu}(\mathrm{I})$ and $\mathrm{Ag}(\mathrm{I})$ complex formation with the hydrophilic phosphine 1,3,5-triaza-7-phosphadamantane in different ionic media. How to estimate the effect of a complexing medium. Dalton Trans. 2017;46:1455-66.

24. Endrizzi F, Melchior A, Tolazzi M, Rao L. Complexation of 
uranium(VI) with glutarimidoxioxime: thermodynamic and computational studies. Dalton Trans. 2015;44:13835-44.

25. Melchior A, Tolazzi M, Polese P, Zanonato PL. Thermodynamics of complex formation of silver(I) with N-donor ligands in non-aqueous solvents. J Therm Anal Calorim. 2017;130:461-9.

26. Credendino R, Minenkov Y, Liguori D, Piemontesi F, Melchior A, Morini G, Tolazzi M, Cavallo L. Accurate experimental and theoretical enthalpies of association of TiCl4 with typical Lewis bases used in heterogeneous Ziegler-Natta catalysis. Phys Chem Chem Phys. 2017;19:26996-7006.

27. Braga PRS, Costa AA, de Macedo JL, Ghesti GF, de Souza MP, Dias JA, Dias SCL. Liquid phase calorimetric-adsorption analysis of Si-MCM-41: evidence of strong hydrogen-bonding sites. Microporous Mesoporous Mater. 2011;139:74-80.

28. Arakaki LNH, Filha VLSA, Germano AFS, Santos SSG, Fonseca MG, Sousa KS, Espínola JGP, Arakaki T. Silica gel modified with ethylenediamine and succinic acid-adsorption and calorimetry of cations in aqueous solution. Thermochim Acta. 2013;556:34-40.

29. Silva Filho EC, Lima LCB, Sousa KS, Fonseca MG, Pereira FAR. Calorimetry studies for interaction in solid/liquid interface between the modified cellulose and divalent cation. J Therm Anal Calorim. 2013;114:5766.

30. Gràcia Lanas $\mathrm{S}$, Valiente $\mathrm{M}$, Aneggi E, Trovarelli A, Tolazzi M, Melchior A. Efficient fluoride adsorption by mesoporous hierarchical alumina microspheres. RSC Adv. 2016;6:42288-96.

31. Elwakeel KZ, El-Sayed GO, Darweesh RS. Fast and selective removal of silver(I) from aqueous media by modified chitosan resins. Int J Miner Process. 2013;120:26-34.

32. Liang X, Xu Y, Sun G, Wang L, Sun Y, Sun Y, Qin X. Preparation and characterization of mercapto functionalized sepiolite and their application for sorption of lead and cadmium. Chem Eng J. 2011;174:436-44. 
33. Liu Y, Sturtevant JM. Significant discrepancies between van't Hoff and calorimetric enthalpies. II. Protein Sci. 1995;4:2559-61.

34. Chaires JB. Possible origin of differences between van't Hoff and calorimetric enthalpy estimates. Biophys Chem. 1997;64:15-23.

35. Liu Y, Sturtevant JM. Significant discrepancies between van't Hoff and calorimetric enthalpies. III. Biophys Chem. 1997;64:121-6.

36. Mizoue LS, Tellinghuisen J. Calorimetric vs. van't Hoff binding enthalpies from isothermal titration calorimetry: $\mathrm{Ba}^{2+}$-crown ether complexation. Biophys Chem. 2004;110:15-24.

37. Uheida A, Iglesias M, Fontàs C, Hidalgo M, Salvadó V, Zhang Y, Muhammed M. Sorption of palladium (II), rhodium (III), and platinum (IV) on $\mathrm{Fe}_{3} \mathrm{O}_{4}$ nanoparticles. J Colloid Interface Sci. 2006;301:402-8.

38. Yean S, Cong L, Yavuz CT, Mayo JT, Yu WW, Kan AT, Colvin VL, Tomson MB. Effect of magnetite particle size on adsorption and desorption of arsenite and arsenate. J Mater Res. 2005;20:3255-64.

39. Madrakian T, Afkhami A, Zadpour B, Ahmadi M. New synthetic mercaptoethylamino homopolymer-modified maghemite nanoparticles for effective removal of some heavy metal ions from aqueous solution. J Ind Eng Chem. 2015;21:1160-6.

40. Liu L, Liu S, Zhang Q, Li C, Bao C, Liu X, Xiao P. Adsorption of $\mathrm{Au}(\mathrm{III}), \mathrm{Pd}(\mathrm{II})$, and $\mathrm{Pt}(\mathrm{IV})$ from aqueous solution onto graphene oxide. J Chem Eng Data. 2013;58:209-16.

41. Spieker WA, Liu J, Miller JT, Kropf AJ, Regalbuto JR. An EXAFS study of the co-ordination chemistry of hydrogen hexachloroplatinate(IV): 1. Speciation in aqueous solution. Appl Catal A Gen. 2002;232:219-35.

42. Rangabhashiyam S, Anu N, Giri Nandagopal MS, Selvaraju N. Relevance of isotherm models in biosorption of pollutants by agricultural byproducts. J Environ Chem Eng. 2014;2:398-414.

43. Butt H-J, Graf K, Kappl M. Physics and chemistry of interfaces. 
Weinheim: Wiley-VCH Verlag GmbH \& Co. KGaA; 2003.

44. Kammerer J, Carle R, Kammerer DR. Adsorption and ion exchange: basic principles and their application in food processing. J Agric Food Chem. 2011;59:22-42.

45. Worch E. Adsorption technology in water treatment-fundamentals, processes, and modeling. Berlin: De Gruyter; 2012.

46. Comuzzi C, Polese P, Melchior A, Portanova R, Tolazzi M.

SOLVERSTAT: a new utility for multipurpose analysis. An application to the investigation of dioxygenated $\mathrm{Co}$ (II) complex formation in dimethylsulfoxide solution. Talanta. 2003;59:67-80.

47. Del Piero S, Melchior A, Polese P, Portanova R, Tolazzi M. A novel multipurpose excel tool for equilibrium speciation based on NewtonRaphson method and on a hybrid genetic algorithm. Ann Chim. 2006;96:2949.

48. Sadeghi S, Rad FA, Moghaddam AZ. A highly selective sorbent for removal of $\mathrm{Cr}(\mathrm{VI})$ from aqueous solutions based on Fe3O4/poly(methyl methacrylate) grafted Tragacanth gum nanocomposite: optimization by experimental design. Mater Sci Eng C. 2014;45:136-45.

49. Marcus Y. Ion solvation. New York: Wiley; 1985.

50. Barczak M, Dobrzyńska J, Oszust M, Skwarek E, Ostrowski J, Zięba E, Borowski P, Dobrowolski R. Synthesis and application of thiolated mesoporous silicas for sorption, preconcentration and determination of platinum. Mater Chem Phys. 2016;181:126-35.

51. Wang J, Li J, Wei J. Adsorption characteristics of noble metal ions onto modified straw bearing amine and thiol groups. J Mater Chem A. 2015;3:18163-70.

52. Zheng H, Hu D, Zhang L, Ma C, Rufford T. Thiol functionalized mesoporous silicas for selective adsorption of precious metals. Miner Eng. 2012;35:20-6. 
